\title{
PERANCANGAN VIDEO COMPANY PROFILE PADA HOTEL de JAVA BANDUNG
}

\author{
Dion Eko Valentino, Muhamad Jodi Hardiansyah ${ }^{1}$ \\ Politeknik LP3I Kampus K Pekanbaru, \\ Politeknik LP3I Bandung ${ }^{1}$ \\ e-mail :dion.plb@gmail.com
}

\begin{abstract}
Abstrak : Penelitian yang dilakukan bertujuan untuk perancangan video Company Profile pada Hotel de Java Bandung dengan menggunakan sofware adobe premiere pro cc. Penelitian ini dilakukan karena masih belum ada penerapan Video Company Profile yang diaplikasikan di hotel serta tidak ada bentuk promosi hotel dengan menggunakan media Visual atau video. Metode penelitian yang di gunakan adalah metode analisis deskriptif yaitu penulis menggambarkan hasil observasi dan menganalisa data yang diperoleh di lapangan. Setelah melakukan analisis dan pembahasan masalah, penulis membuat visualisasi dengan menggunakan adobe premiere pro cc guna membantu perusahaan agar lebih di ketahui masyarakat luas dalam bentuk video atau visual.
\end{abstract}

Kata Kunci : Company Profile, Video, Video Editing

\section{Pendahuluan}

Perkembangan jaman menuntut manusia untuk selalu berkembang dalam berbagai bidang, termasuk dalam pembuatan media yang dapat memberikan suatu informasi untuk masyarakat luas. Saat ini salah satu media yang cukup populer dikalangan masyarakat adalah video yang dapat memberikan informasi secara audio dan visual dimana masyarakat melihat (menonton) dan/atau mendengarkan informasi yang akan disampaikan secara menarik. Masyarakat tidak lagi harus membaca ataupun bersusah payah mencari informasi mengenai suatu hal dalam sebuah artikel. Hal ini menjadi salah satu peluang yang digunakan para pembisnis dalam mengenalkan dan memasarkan produk perusahaan mereka kepada masyarakat luas.

Seiring dengan perkembangan teknologi dan multimedia, metode pemasaran yang efektif dan efisien juga mengalami perubahan. Harus di akui bahwa pemasaran dan promosi melalui digital menjadi alternatif pilihan yang sangat efektif. Media digital seperti video dan infographic telah menjadi pilihan yang banyak dipilih para pembisnis untuk memberikan informasi menarik seputar perusahaan mereka kepada masyarakat. Hal ini tentu saja bukan tanpa alasan mengingat perkembangan jejaring sosial dan komunikasi digital mengalami perkembangan yang pesat. Salah satu upaya yang dapat dilakukan seorang pembisnis dalam memberikan informasi seputar perusahaannya yakni melalui metode pemasaran menggunakan Video Company Profile

Video Company Profile adalah bentuk lain dari Company Profile dengan format audio visual berupa cuplikan-cuplikan video yang dipercantik dengan tampilan animasi dan grafis, ilustrasi musik yang sesuai narasi, dan menampilkan host bila diperlukan. Company Profile sendiri berisi informasi seputar perusahaan, mulai dari sejarah, visi dan misi, produk jangkauan atau tempat. Selain itu, Video Company Profile juga merupakan salah satu cara yang dapat digunakan untuk meningkatkan brand awareness kepada 
masyarakat yang mana Video Company Profile sendiri dapat diaplikasikan untuk presentasi, marketing tools, kebutuhan dokumentasi, komunikasi, dan publikasi perusahaan secara luas.

Namun masih banyak perusahaan yang belum mengenal atau mengaplikasikan teknik atau metode pemasaran menggunakan Video Company Profile, sehingga tidak banyak masyarakat yang mengetahui informasi seputar perusahaan secara menyeluruh, sementara Video Company Profile merupakan salah satu sarana yang sangat penting dalam mempromosikan perusahaan salah satunya bisnis hotel, yang mana dengan menggunakan teknik Video Company Profile sebuah hotel dapat memberikan informasi seputar lokasi serta fasilitas disediakan pihak hotel ataupun sebagainnya. Video Company Profile juga bisa digunakan untuk mempromosikan serta mengiklankan hotel para pembisnis kepada masyarakat luas.

Berdasarkan uraian di atas, maka penulis hendak melakukan penelitian di salah satu hotel yang berada di Bandung untuk meninjau penerapan dan pengaplikasian Video Company Profile di perusahaan tersebut.

\section{Landasan Teori}

\subsection{Pengertian Video}

Menurut Ayuningtyas [4], Video merupakan gabungan gambar-gambar mati yang dibaca berurutan dalam satu waktu dengan kecepatan tertentu. Sedangkan menurut Binanto [5] kata video berasal dari kata latin yang berarti "saya lihat" Video adalah teknologi pemprosesan sinyal elektronik yang mewakilkan gambar bergerak. Sehingga dapat disimpulakn video merupakan sebuah kumpulan gambar-gambar mati yang bergerak dalam suatu framedan kecepatan tertentu dalam sebuah bentuk dimensi yang berbeda.

Dalam kaitannya, Video Company Profile dapat digunakan disebuah perusahaan untuk mempromosikan identitas sebuah perusahaan kepada khalayak banyak atau publik agar informasi dari sebuah perusahaan dapat diterima dan diketahui oleh publik dengan mudah melalui media audio visual serta memudahkan perusahaan untuk memberitahukan perusahaannya dengan mudah.

\subsection{Pengertian Company Profile}

Menurut Anshori [3], Company Profile merupakan sebuah rekaman yang ditayangkandi TV dan media Audio Visual lainnya, yang mempresentasikan sebuah identitas dan pencitraan baik terhadap suatu perusahaan. Company Profile disini lebih bersifat multimedia dibangun dari sebuah storyline atau Storyboard, disusun dari pengambilan gambar, dikombinasi dengan rangkaian logo, poto, teks, bagan, grafik yang dijelaska secara seimbang dengan backsound yang seimbang. Menurut Herman Thuan [19], Company Profile adalah ringkasan deskripsi informasi sebuah perusahaan (corporate) dimana perusahaan dapat memilih poin-poin apa saja yang ingin di sampaikan secara terbuka kepada publik sesuai tujuan. Point-point yang ada dalam Company Profile seperti sejarah perusahaan.

Sejarah perusahaan, misalnya, profile pendiri, perkembangan perusahaan secara umum dan filosofi perusahaan (pandangan atau ideologi dasar perusahhan). Berikutnya ada identitas perusahaan. Misalnya, logo, seragam, interior gedung / kantor, visi, misi, lokasi 
perusahaan ( termasuk kantor cabang bila ada ), sambutan pimpinan dalam segala hal yang sangat berpengaruh pada aktivitas perusahaan, dan rencana jangka panjang. Dan Sistem pelayanan dan aktivitas. Misalnya, presentasi keunggulan perusahaan, dan deskripsi produk atau jasa yang di tawarkan. Pembuatan Company Profile kini lebih mengedapankan pemanfaatan teknologi perangkat lunak.

Company Profile adalah produk tulisan praktis yang berisi gambaran umum perusahaan. Sedangkan menurut kamus besar Inggris-Indonesia (John M. dan Shadily) dikutip dari Alif Aminnudin [1], Company Profile berasal dari dua kata bahasa inggris yang memiliki pengertian yang berbeda tetapi memiliki arti yang saling terkait, yakni Company, dan Profile. Company artinya perusahaan, maskapai, frima, perseroan, persekutuan, kompi, dan rombongan. sedangkan Profile merupakan tampang, penampang, dan riwayat.

Secara umum isi dari Company Profile mencangkup antara lain:

1. Sejarah perusahaan. Mencangkup antara lain pendiri perusahaan, jajaran Direksi, asal muasal, sejarah pengembangan dll.

2. Filosofis Perusahaan, bisa disebut sebagai pandangan atau ideologi dasar-dasar perusahaan.

3. Budaya perusahaan, adalah nilai-nilai kunci dan konsep bersama yang membentuk citra anggota organisasi terhadap organisasinya. Misalnya etos kerja yang tinggi, maju untuk semua, dsb.

4. Sambutan dari pimpinan (direktur utama atau komisaris utama) tentang segala hal yang sangat berpengaruh pada aktivitas perusahaan dan rencana jangka panjang.

5. Identitas perusahaan, termasuk logo, uniform, interior, gedung dan kantor, kualitas cetakan atau kualitas audio visualnya.

6. Visi, misi, strategi perusahaan, termasuk komitmen perusahaan untuk meraih kemajuan.

7. Alamat cabang-cabang, semakin banyak cabang-cabang diwilayah menunjukan jalur distribusi yang merata.

8. Gambaran tentang SDM, ceritakan orang-orang dibalik operasional perusahaan, siapa saja figur pengendali dijajaran manajemen termasuk tokoh yang berpengaruh dimasyarakat yang berkaitan dengan perusahaan.

9. Sistem pelayanan dan fasilitas yang disediakan. Gambaran mengenai kelebihan perusahaan dari sisi yang membedakan dari kompetitor.

10. Prestasi dan keunggulan perusahaan, termasuk segla hal yang telah dilakukan perusahaan untuk kepentingan masyarakat.

11. Laporan perkembangan perusahaan, termasuk informasi keuangan perusahaan.

12. Deskripsi tentang produk-produk dan jasa utama yang ditawarkan.

13. Program pengembangan dimasa mendatang.

Sedangkan secara fungsional fungsi dari Company Profile adalah sebagai berikut :

1. Representasi perusahaan. Comapany profile merupakan sebuah bentukgambaran dari perusahaan, sehingga publik tidak harus bersusah payah untuk mencari informasi terkait perusahaan. Hal ini juga dapat digunakan dalam rangka 
membangun citra perusahaan untuk bisa memiliki pemahaman yang mendalam mengenai sebuah perusahaan.

2. Bisa digunakan untuk melengkapi komunikasi lisan demi terciptanya mutual understanding atau saling memahami satu dengan yang lainnya.

3. Menghemat waktu transaksi. Pihak-pihak lain yang bersangkutan dengan bisnis perusahaan tidak perlu menanyakan secara detail tentang perusahaan, produk, pasar, misi, visi, dll. Hal itu dapat dipelajari melalui Company Profile.

4. Membangun identitas dan citra Korporat. Company Profile yang dikemas menarik, detail, jelas, dan mewah dapat mencerminkan wajah perusahaan dimata publik sebagai sebuah perusahaan yang besar dan bonafit.

Jadi dapat disimpulkan bahwa Company Profile merupan sebuah media dari jati diri sebuah perusahaan mengenai seluruh aktivitas, keunggulan, budaya perusahaan serta segala bentuk yang dimiliki oleh sebuah perusahaan yang bertujuan untuk mengenalkan atau memberitahukan apa yang dimiliki oleh sebuah perusahaan kepada audience atau khalayak umum sehingga membuat mereka tertarik untuk melihatnya.

\subsection{Pengertian Storyboard}

Menurut Sargio Paez dalam bukunya yang berjudul Profesional Storyboarding [14], pengertian storyboard adalah deskripsi pada setiap scene yang bertujuan untuk menjelaskan atau menggambarkan objek multimedia dan perilakukan dengan jelas.

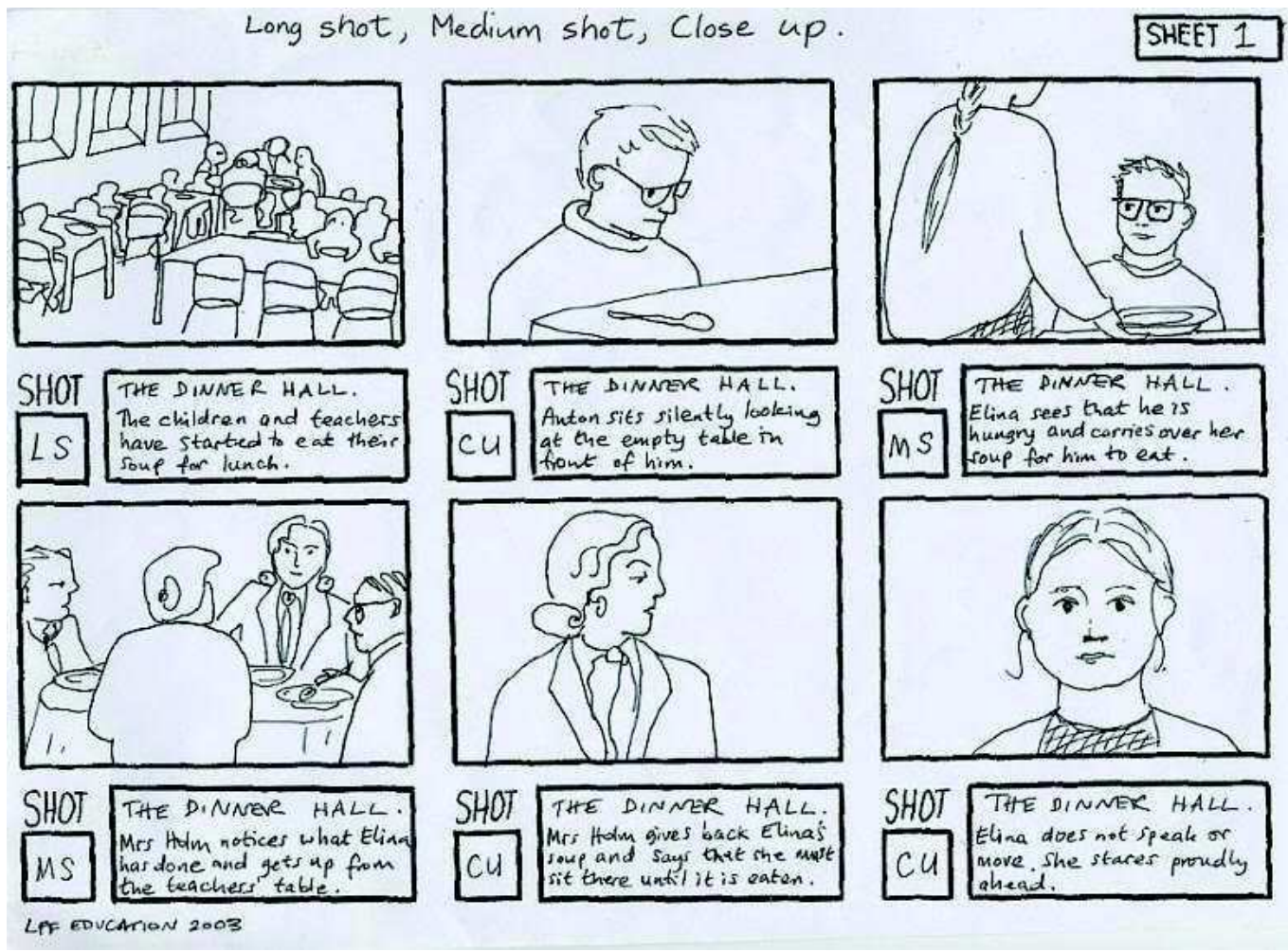

Gambar 1. Storyboard

Menurut Luther dalam bukunya yang berjudul memahami storyboard [11], Storyboard diartikan sebagai deskripsi yang terdapat pada setiap scene yang bertujuan untuk menggambarkan objek multimedia dan perilakunya secara jelas. Menurut Halaz dalam bukunya yang berjudul Merancang storyboard [8], "Storyboard merupakan rangkai 
gambar yang dibuat secara manual untuk menggambarkan atau menjelaskan suatu jalan cerita.

\subsection{Pengertian Storyline}

Menurut Aminudin dalam bukunya yang berjudul about storyline [1], Storyline merupakan rangkayan cerita yang dibentuk oleh tahapan-tahapan peristiwa sehingga menjalani suatu cerita bisa berbentuk dalam rangkayan peristiwa yang berbagai macam. Alur atau plot ialah struktur rangkaian kejadian dalam cerita yang disusun sebagai sebuah interelasi fungsional yang sekaligus menandai urutan bagian-bagian dari keseluruhan fiksi semi. Menurut Stanton dalam buku Nurgiyantoro [13], Mengemumukakan bahwa plot ialah cerita yang berisi urutan kejadian, namun tiap kejadian itu hanya dihubungkan secara sebab akibat peristiwa yang satu disebabkan atau menyebabkan terjadinya peristiwa yang lain.". Menurut Foster dalam buku Tuloli [18], Mengemukakan plot merupakan rentetan peristiwa dalam suatu fiksi "novel dan cerpen" tersusun dalam waktu berdasarkan hukum sebab akibat. Plot sama dengan kerangka cerita yang menjadi susunan strukutur cerita.

\begin{tabular}{|c|c|c|c|c|c|}
\hline No & Topik & Narasi & Musik & Adegan & Durasi \\
\hline 1 & Opening & $\begin{array}{l}\text { - Tanpa Narasi } \\
\text { - Judul "Polusi udara dan Efek } \\
\text { Rumah kaca" }\end{array}$ & $\begin{array}{l}\text { Music } \\
\text { keras }\end{array}$ & $\begin{array}{l}\text { Animasi } \\
\text { - Judul } \\
\text { - Sponsor } \\
\text { - Lembaga penanggungjawab } \\
\text { - Dll }\end{array}$ & $20 "$ \\
\hline 2 & $\begin{array}{l}\text { Sumber- } \\
\text { sumber } \\
\text { pencemaran } \\
\text { udara }\end{array}$ & $\begin{array}{l}\text { - Narator : Selamat ber jumpa } \\
\text { kembali para siswa dalam } \\
\text { program pendidikan Sekolah. } \\
\text { Tentu kalian sudah dapat } \\
\text { menduga topic apa yang akan kita } \\
\text { bahas kali ini ? } \\
\text { Ya, benar, kali ini kita akan } \\
\text { membahas tentang polusi udara } \\
\text { dan efek rumah kaca. } \\
\text { - Narator : Ada bermacam-macam } \\
\text { polusi, tapi kali ini kita akan } \\
\text { membahas tentang polusi udara. Zat } \\
\text { pencemar udara dapat bersumber } \\
\text { dari alam maupun buatan manusia. } \\
\text { Polusi udara dapat disebabkan } \\
\text { oleh kegiatan pembakaran yang } \\
\text { menghasilkan asap tebal, gas } \\
\text { buangan bahan bakar dari pabrik } \\
\text { yang berbahaya bagi kesehatan } \\
\text { atau lingkungan. Demikian juga } \\
\text { dengan kendaraan bermotor, dari } \\
\text { hasil pembakaran tersebut akan } \\
\text { dikeluarkan asap tebal dan }\end{array}$ & $\begin{array}{r}\text { - Tanpa } \\
\text { music } \\
\text { - Musik } \\
\text { lembut }\end{array}$ & $\begin{array}{l}\text { - Narator menjelaskan } \\
\text { tentang sumber-sumber } \\
\text { pencemaran udara } \\
\text { Tayangan/video sumber- } \\
\text { sumber pencemaran udara } \\
\text { misalnya kendaraan } \\
\text { bermotor yang } \\
\text { mengeluarkan asap } \\
\text { dijalanan,asap pabrik, asap } \\
\text { gunung berapi, pembakaran } \\
\text { sampah. } \\
\text { Ditampilkan power point : } \\
5 \text { unsur utama pencemaran } \\
\text { udara: } \\
\text { - CO2 } \\
\text { - Oksida belerang } \\
\text { - Oksida Nitrogen } \\
\text { - Partikel-partikel }\end{array}$ & \\
\hline
\end{tabular}

Gambar 2. Storyline

Macam-macam alur

a. Alur maju/progresif

Menurut Andya Primanda dalam bukunya yang berjudul Buku Pintar Penyunting Naskah [15], Alur maju adalah urutan secara kronologis pada jalan cerita yang disajikan oleh penulis secara berkesinambungan dari tahap pengenalan dan penyelesaian. Alur maju disebut juga dengan alur progresif karena alurnya berurutan dan tidak diacak sama sekali. 
b. Alur mundur

Menurut Arry Rahmawan dalam buku Cara Menyelesaikan Naskah Buku [16], Alur mundur adalah tahapan-tahapan proses jalannya suatu cerita secara tidak urut. Penulis menyajikan ceritanya dimulai dari konflik menuju penyelesaian, kemudian menceritakan kembali latar belakang timbulnya konflik tersebut.

c. Alur Campuran

Menurut Janner Simarmata dalam bukunya [17], Alur campuran adalah gabungan dari alur maju dan alur mundur. Penulis menyajikan ceritanya secara kronologis dan kemudian pada suatu waktu tertentu, penulis menceritakan kembali (Flash Back) kisah masa lalu. Untuk mengidentifikasi alur campuran kita harus cukup jeli dalam mengamati alur, biasanya alur campuran cukup sulit ditemukan.

\section{Perancangan Video Company Profile Dengan Mengunakan Adobe Premiere Pro CC}

\subsection{Tahap perancangan}

Langkah pertama yang penulis lakukan adalah mencari informasi terlebih dahulu dengan menanyakan langsung kepada pihak terkait di hotel de java bandung. Dengan Informasi yang didapat, maka kemudian penulis membuat storyline dan storyboard. Setelah storyline dan storyboard selesai penulis berdiskusi dengan pihak hotel untuk mengetahui apakah yang dibuat penulis sudah sesuai dengan kebutuhan dari hotel. Penulis kemudaian melakukan perbaikan dengan menyesuaikan kebutuhan dari pihak hotel. Setelah di perbaiki penulis bertemu kembali dengan pihak hotel untuk persetujuan. Setelah itu, penulis mencocokan jadwal bersama pihak hotel untuk perihal pengambilan gambar. Setelah semua bahan gambar terkumpul, penulis merancang sebuah video dengan menggunakan adobe premiere pro cc. 


\subsection{Sketsa Rancangan Storyline}

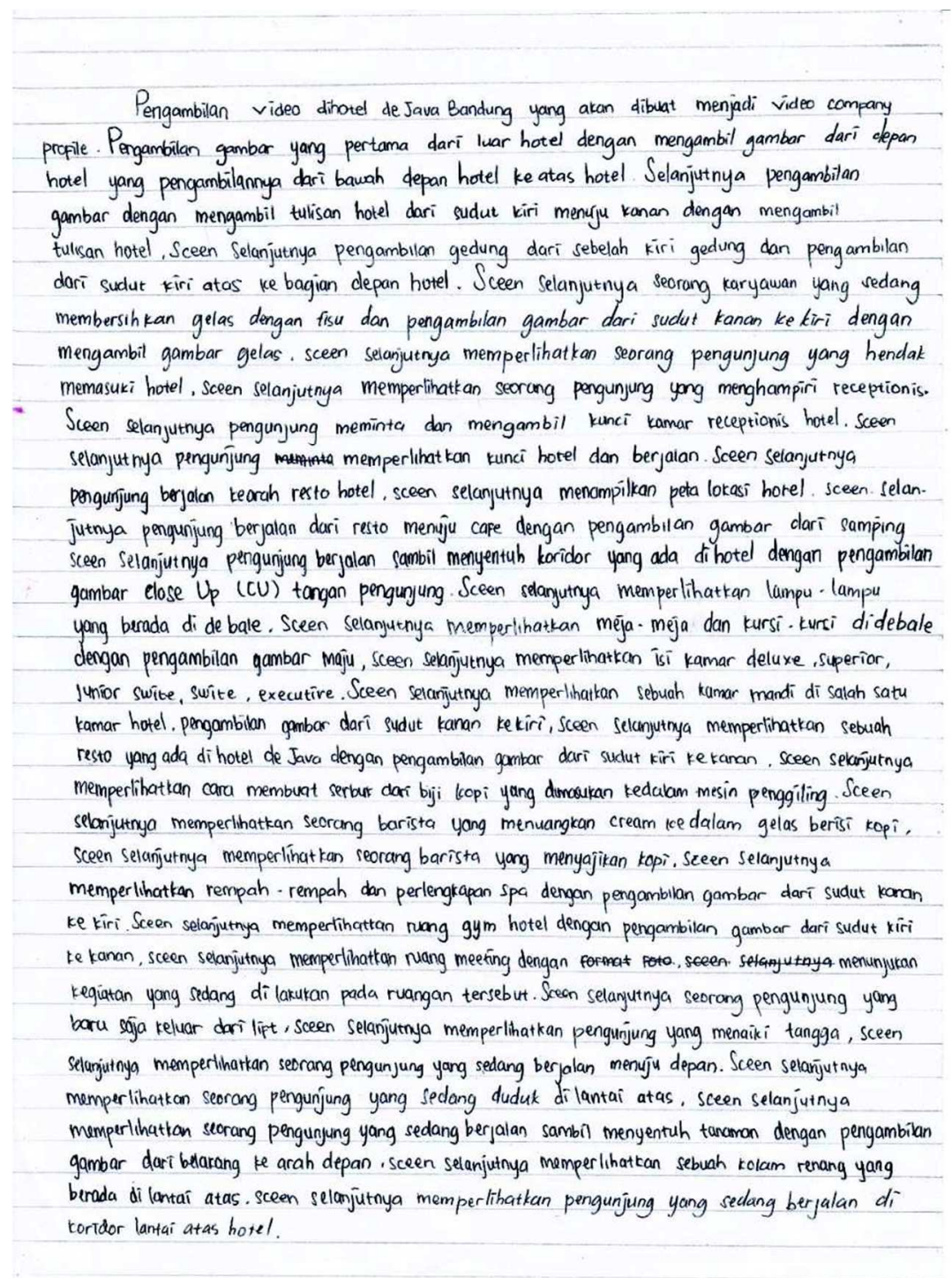

\section{Gambar 3}

Sketsa Storyline

\section{Proses Produksi}

Dalam proses produksi tahap pembuatan proses editing yang di rancang dengan melihat storyboard dan storyline yang telah di buat sebelumnya dan kemudian hasil dari perekaman akan di masukan ke dalam perangkat lunak adobe premiere pro cc yang akan di olah dengan perancangan di dalam sebuah sofware adobe premiere pro cc sehingga akan menjadikan hasil video text audio dan gambar yang di gabungkan dan diatur sedemikian rupa sehingga menjadinya hasil visual yang tersusun sesuai rancangan. 


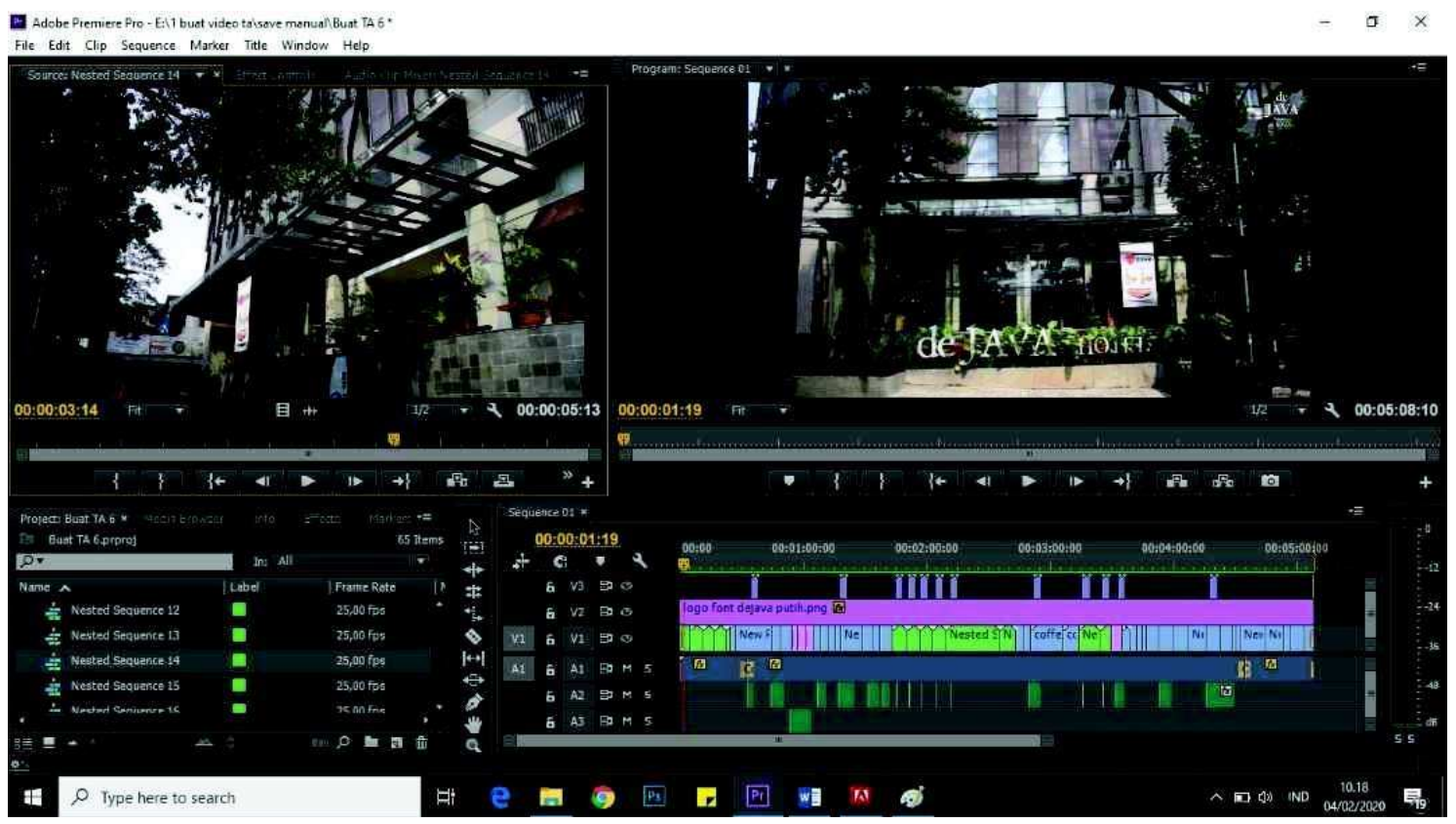

Gambar 4. Proses Produksi

\section{Storyboard Produksi}

Storyboard produksi merupakan hasil akhir atau hasil jadi yang akan dijadikan panduan editor untuk menyusun gambar, teks, video dan audio agar menjadi satu video yang utuh. Didalam storyboard ini penulis juga menyisipkan keterangan tambahan pada kolom, yang bertujuan agar memudahkan editor dalam penyusunan. Dibawah ini merupakan kolom storyboard hasil akhir.

\begin{tabular}{|c|c|c|}
\hline No & Adegan & Durasi \\
\hline 1 & $\frac{1}{2 \ldots+n}$ & $\begin{array}{l}\text { - } \text { Durasi : 1-5 detik } \\
\text { - Lokasi : teras depan hotel } \\
\text { - Sound FX : Corporate } \\
\text { Background } \\
\text { - Efek : Cross Dissolve } \\
\text { - Teknik : long shoot } \\
\text { - Pengambilan : dari bawah } \\
\text { ke atas } \\
\text { - Gambar : depan hotel } \\
\text { - Aktor : - }\end{array}$ \\
\hline 2 & $\cos ^{2}$ & $\begin{array}{ll}\text { - } & \text { Durasi : 5-11 detik } \\
\text { - } & \text { Lokasi : Gambar depan } \\
& \text { tulisan hotel } \\
\text { - } & \text { Sound FX : Corporate } \\
& \text { Background } \\
\text { - } & \text { Efek : Cross Dissolve } \\
\text { - } & \text { Teknik : close up } \\
\text { - Pengambilan : dengan } \\
\\
\text { pengambilan gambar dari }\end{array}$ \\
\hline
\end{tabular}




\begin{tabular}{|c|c|c|}
\hline No & Adegan & Durasi \\
\hline & & $\begin{array}{l}\text { samping kiri menuju } \\
\text { samping kanan } \\
\text { - Gambar : Tulisan hotel } \\
\text { - Aktor : - }\end{array}$ \\
\hline 3 & $=\frac{1}{n=0}$ & $\begin{array}{l}\text { - } \\
\text { - Lurasi : 11-17 detik } \\
\text { - Sokasi : depan hotel } \\
\text { Background } \\
\text { - Efek : Cross Dissolve } \\
\text { - Teknik : long shoot } \\
\text { - Pengambilan : dari luar } \\
\text { samping atas ke bawah } \\
\text { - Gambar : luar samping } \\
\text { depan hotel } \\
\text { - Aktor : - }\end{array}$ \\
\hline 4 & $=$ & $\begin{array}{l}\text { - Durasi : } 17-22 \text { detik } \\
\text { - Lokasi : di dalam hotel } \\
\text { - Sound FX : Corporate } \\
\text { Background } \\
\text { - Efek : Cross Dissolve } \\
\text { - Teknik : close up } \\
\text { - Pengambilan : memutari } \\
\text { gelas } \\
\text { - Gambar : gelas } \\
\text { - } \text { Aktor : laki-laki } \\
\end{array}$ \\
\hline 5 & 5 & $\begin{array}{l}\text { - } \text { Durasi : } 22 \text { - } 24 \text { detik } \\
\text { - Lokasi : atas gedung } \\
\text { - Sound FX : Corporate } \\
\text { Background } \\
\text { - Efek : Cross Dissolve } \\
\text { - Teknik : maju } \\
\text { - Pengambilan : maju } \\
\text { diantara gelas } \\
\text { - Gambar : gelas di atas meja } \\
\text { - } \text { Aktor : - } \\
\end{array}$ \\
\hline 6 & 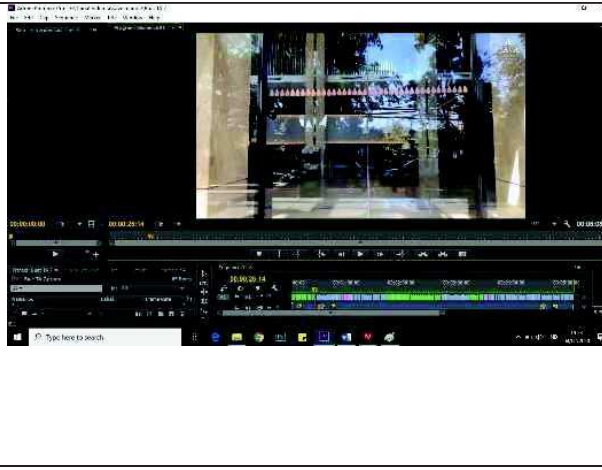 & $\begin{array}{l}\text { - Durasi : } 24-27 \text { detik } \\
\text { - Lokasi : depan pintu hotel } \\
\text { - Sound FX : Corporate } \\
\text { Background } \\
\text { - Efek : Cross Dissolve } \\
\text { - Teknik : close up } \\
\text { - Pengambilan : maju seolah } \\
\text { masuk ke dalam } \\
\text { - Gambar : pintu hotel } \\
\text { - Aktor : - }\end{array}$ \\
\hline
\end{tabular}




\begin{tabular}{|c|c|c|}
\hline No & Adegan & Durasi \\
\hline 7 & 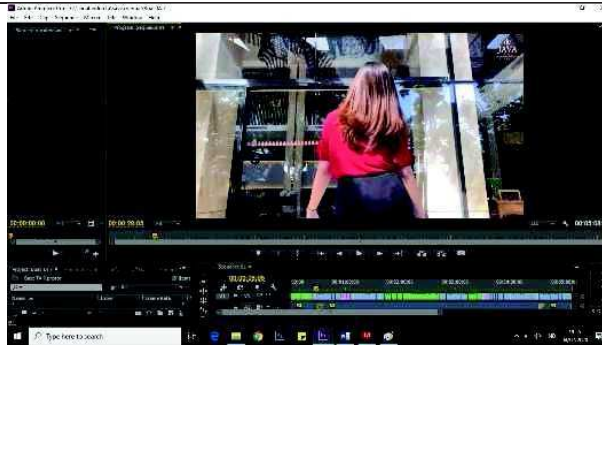 & $\begin{array}{l}\text { - } \text { Durasi : } 27 \text { - } 45 \text { detik } \\
\text { - Lokasi : depan teras hotel } \\
\text { - Sound FX : Corporate } \\
\text { Background } \\
\text { - Efek : Cross Dissolve } \\
\text { - Teknik : close up } \\
\text { - Pengambilan : belakang } \\
\text { - Gambar : masuk kedalam } \\
\text { hotel } \\
\text { - Aktor : Perempuan }\end{array}$ \\
\hline 8 & $=\frac{\cdots}{\cdots}$ & $\begin{array}{l}\text { - Durasi : } 45-49 \text { detik } \\
\text { - Lokasi : lobby } \\
\text { - Sound FX : Corporate } \\
\text { Background } \\
\text { - Efek : Cross Dissolve } \\
\text { - Teknik : long shoot } \\
\text { - Pengambilan : samping } \\
\text { - Gambar : pengambilan } \\
\text { kunci } \\
\text { - Aktor : Perempuan dan laki- } \\
\text { laki } \\
\end{array}$ \\
\hline 9 & a & $\begin{array}{l}\text { - Durasi : } 49-55 \text { detik } \\
\text { - Lokasi : lobby hotel } \\
\text { - Sound FX : Corporate } \\
\text { Background } \\
\text { - Efek : Cross Dissolve } \\
\text { - Teknik : close up } \\
\text { - Pengambilan } \\
\text { - Gambar : samping } \\
\text { - Aktor : Perempuan dan laki- } \\
\text { laki }\end{array}$ \\
\hline 10 & 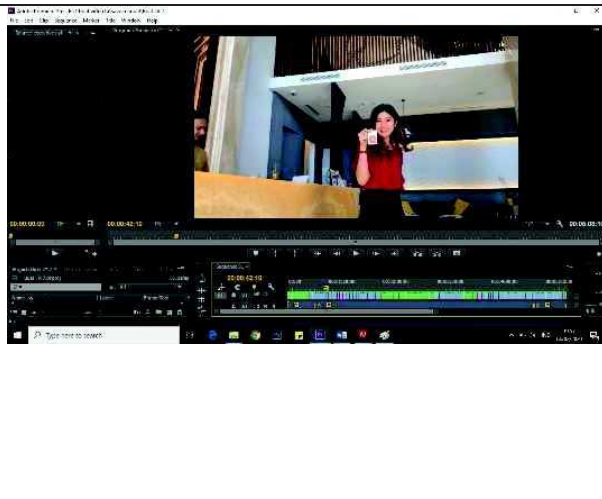 & $\begin{array}{l}\text { - Durasi : } 55 \text { detik-1,5 } \\
\text { menit } \\
\text { - Lokasi : lobby hotel } \\
\text { - Sound FX : Corporate } \\
\text { Background } \\
\text { - Efek : Cross Dissolve } \\
\text { - Teknik : close up } \\
\text { - Pengambilan : depan } \\
\text { - Gambar : memperlihatkan } \\
\text { kunci } \\
\text { - Aktor : Perempuan }\end{array}$ \\
\hline
\end{tabular}




\begin{tabular}{|c|c|c|}
\hline No & Adegan & Durasi \\
\hline 11 & 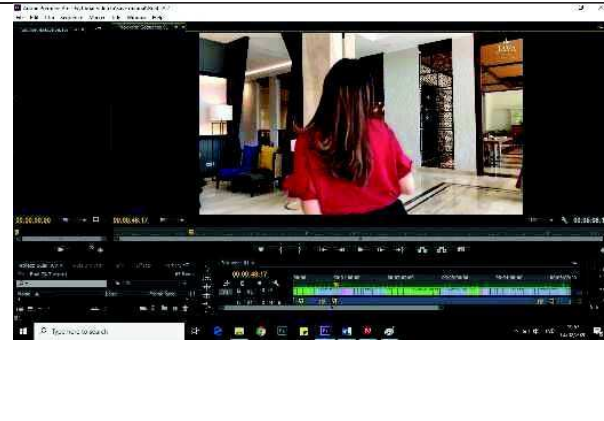 & $\begin{array}{ll}\text { - } & \text { Durasi : 1,5 - 1,8 menit } \\
\text { - } & \text { Lokasi : lobby } \\
\text { - } & \text { Sound FX : Corporate } \\
& \text { Background } \\
\text { - } & \text { Efek : Cross Dissolve } \\
\text { - } & \text { Teknik : long shoot } \\
\text { - Pengambilan : belakang } \\
\text { - Gambar : masuk lobby } \\
\text { - Aktor : Perempuan }\end{array}$ \\
\hline 12 & a. & $\begin{array}{ll}\text { - } & \text { Durasi : } 1,8-1,12 \text { menit } \\
\text { - } & \text { Lokasi : - } \\
\text { - } & \text { Sound FX : Corporate } \\
& \text { Background } \\
\text { - } & \text { Efek : Cross Dissolve } \\
\text { - } & \text { Teknik : - } \\
\text { - Pengambilan : belakang } \\
\text { - Gambar :- } \\
\text { - Aktor : - }\end{array}$ \\
\hline 13 & 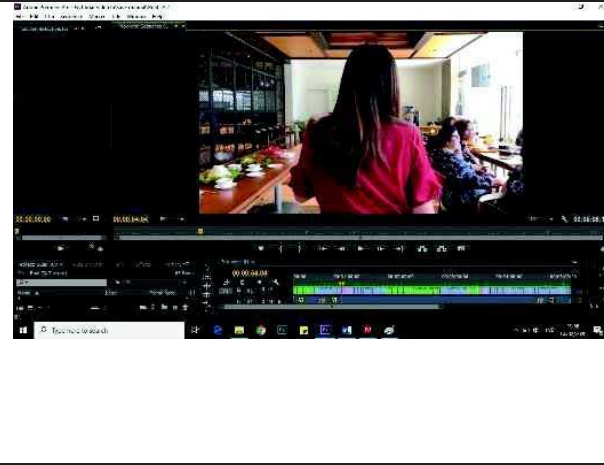 & $\begin{array}{l}\text { - Durasi : } 1,12-1,16 \text { menit } \\
\text { - Lokasi : de bale } \\
\text { - Sound FX : Corporate } \\
\text { Background } \\
\text { - Efek : Cross Dissolve } \\
\text { - Teknik : long shoot } \\
\text { - Pengambilan : samping } \\
\text { - Gambar : berjalan ke de } \\
\text { bale } \\
\text { - Aktor : Perempuan }\end{array}$ \\
\hline 14 & 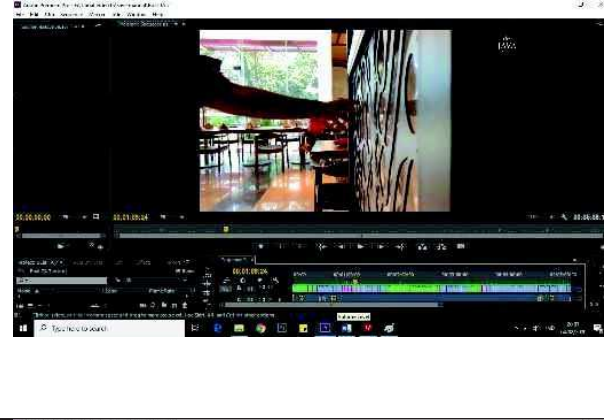 & $\begin{array}{l}\text { - Durasi : } 1,16-1,19 \text { menit } \\
\text { - Lokasi : de bale } \\
\text { - Sound FX : Corporate } \\
\text { Background } \\
\text { - Efek : Cross Dissolve } \\
\text { - Teknik : close up } \\
\text { - Pengambilan : maju } \\
\text { - Gambar : tangan } \\
\text { - Aktor : perempuan }\end{array}$ \\
\hline 15 & 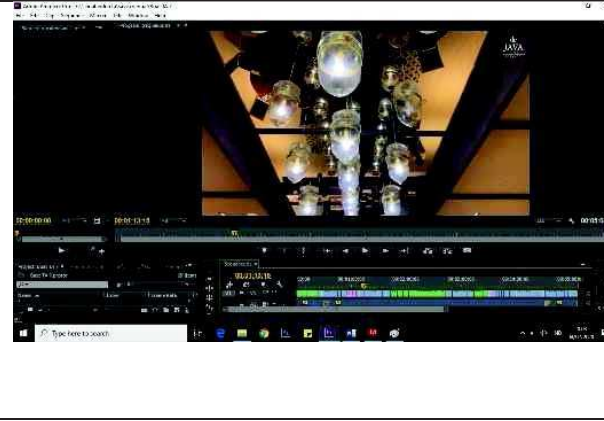 & $\begin{array}{l}\text { - Durasi : 1,19-1,29 menit } \\
\text { - Lokasi : de bale } \\
\text { - Sound FX : Corporate } \\
\text { Background } \\
\text { - Efek : Cross Dissolve } \\
\text { - Teknik : long shoot } \\
\text { - Pengambilan : atas } \\
\text { - Gambar : lampu hotel } \\
\text { - Aktor : - }\end{array}$ \\
\hline
\end{tabular}




\begin{tabular}{|c|c|c|}
\hline No & Adegan & Durasi \\
\hline 16 & 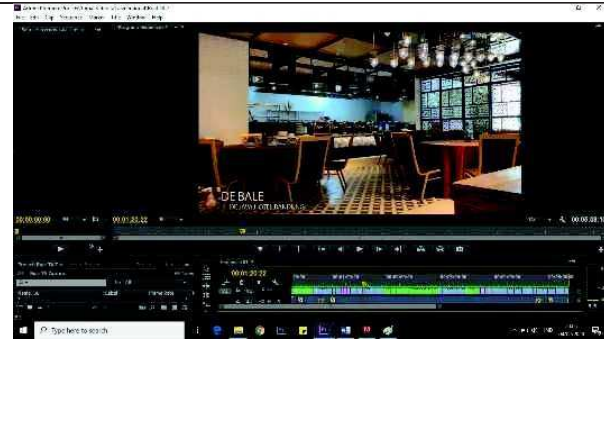 & $\begin{array}{l}\text { - } \text { Durasi : 1,29-1,34 menit } \\
\text { - Lokasi : de bale } \\
\text { - Sound FX : Corporate } \\
\text { Background } \\
\text { - Efek : Cross Dissolve } \\
\text { - Teknik : long shoot } \\
\text { - Pengambilan : maju } \\
\text { - Gambar : meja de bale } \\
\text { - Aktor : - }\end{array}$ \\
\hline 17 & 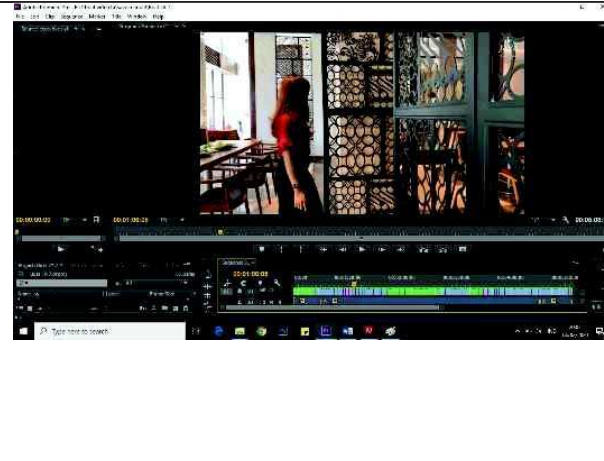 & $\begin{array}{l}\text { - Durasi : } 1,34-1,37 \text { menit } \\
\text { - Lokasi : de bale } \\
\text { - Sound FX : Corporate } \\
\text { Background } \\
\text { - Efek : Cross Dissolve } \\
\text { - Teknik : close up } \\
\text { - Pengambilan : maju } \\
\text { - Gambar : berjalan } \\
\text { - } \text { Aktombelakangi : Perempuan }\end{array}$ \\
\hline 18 & 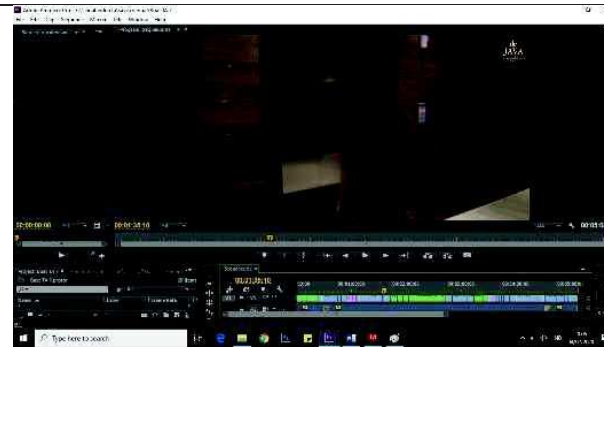 & $\begin{array}{l}\text { - Durasi : } 1.37-1,43 \text { menit } \\
\text { - Lokasi : lift } \\
\text { - Sound FX : Corporate } \\
\text { Background } \\
\text { - Efek : Cross Dissolve } \\
\text { - Teknik : close up } \\
\text { - Pengambilan : maju } \\
\text { - Gambar : belakang } \\
\text { - } \text { Aktor : Perempuan }\end{array}$ \\
\hline 19 & 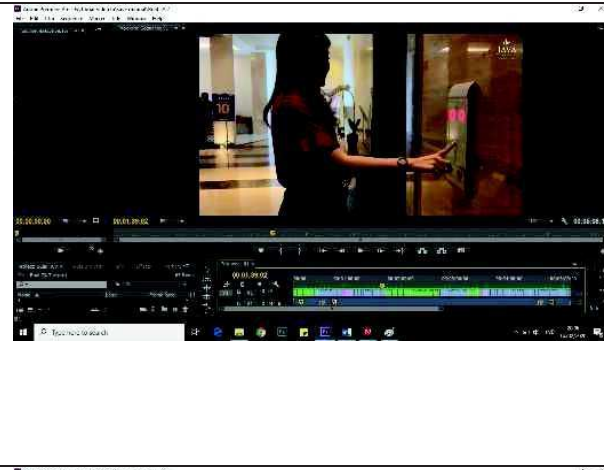 & $\begin{array}{l}\text { - Durasi : } 1,43-1,50 \text { menit } \\
\text { - Lokasi : Lift } \\
\text { - Sound FX : Corporate } \\
\text { Background } \\
\text { - Efek : Cross Dissolve } \\
\text { - Teknik : close up } \\
\text { - Pengambilan : samping } \\
\text { - Gambar : menekan tombol } \\
\text { pada lift } \\
\text { - Aktor : Perempuan }\end{array}$ \\
\hline 20 & 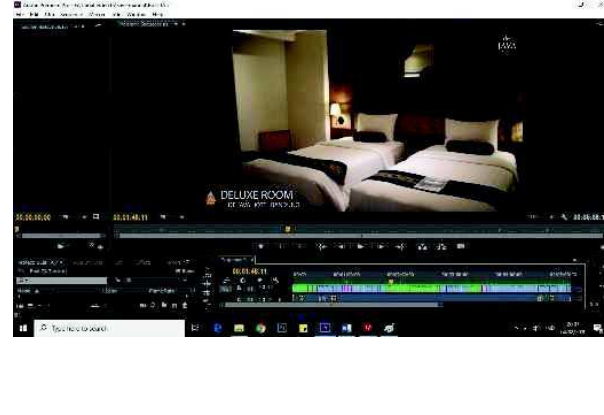 & $\begin{array}{l}\text { - Durasi : 1,50 - 1,57 menit } \\
\text { - Lokasi : kamar hotel } \\
\text { - Sound FX : Corporate } \\
\text { Background } \\
\text { - Efek : Cross Dissolve } \\
\text { - Teknik : long shoot } \\
\text { - Pengambilan : samping } \\
\text { - Gambar : kamar hotel } \\
\text { - Aktor : - }\end{array}$ \\
\hline
\end{tabular}




\begin{tabular}{|c|c|c|}
\hline No & Adegan & Durasi \\
\hline 21 & 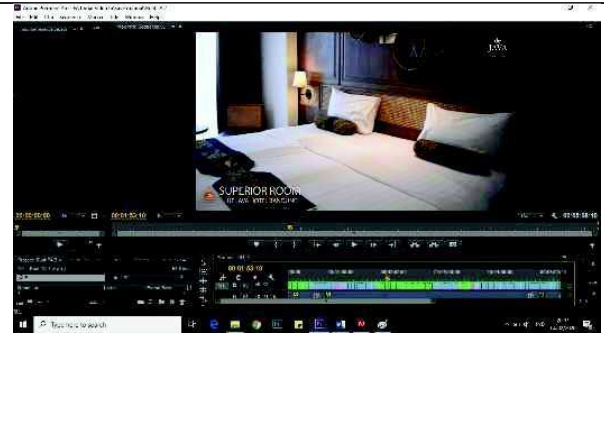 & $\begin{array}{l}\text { - Durasi : 1,57-2,3 menit } \\
\text { - Lokasi : kamar } \\
\text { - } \text { Sound FX : Corporate } \\
\text { Background } \\
\text { - Efek : Cross Dissolve } \\
\text { - Teknik : long shoot } \\
\text { - Pengambilan : samping } \\
\text { - Gambar : kamar hotel } \\
\text { - Aktor : - }\end{array}$ \\
\hline 22 & 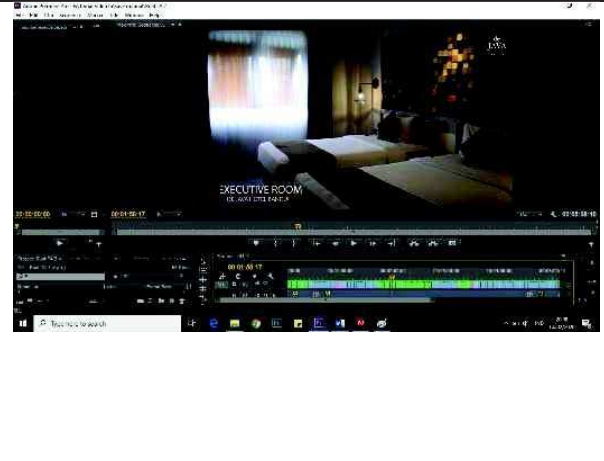 & $\begin{array}{l}\text { - } \text { Durasi : } \\
\text { 2,3 - 2,9 menit } \\
\text { - Lokasi : kamar } \\
\text { - Sound FX : Corporate } \\
\text { Background } \\
\text { - Efek : Cross Dissolve } \\
\text { - Teknik : long shoot } \\
\text { - Pengambilan : samping } \\
\text { - Gambar : kamar hotel } \\
\text { - Aktor : - }\end{array}$ \\
\hline 23 & 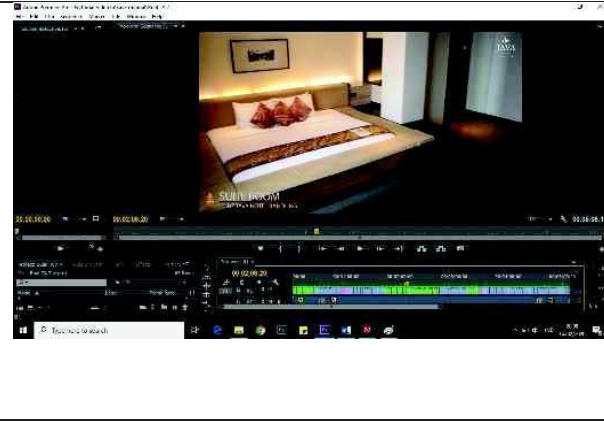 & $\begin{array}{l}\text { - Durasi : 2,9-2,36 menit } \\
\text { - Lokasi : kamar } \\
\text { - Sound FX : Corporate } \\
\text { Background } \\
\text { - Efek : Cross Dissolve } \\
\text { - Teknik : long shoot } \\
\text { - Pengambilan : atas } \\
\text { - Gambar : kamar } \\
\text { - Aktor : - }\end{array}$ \\
\hline 24 & 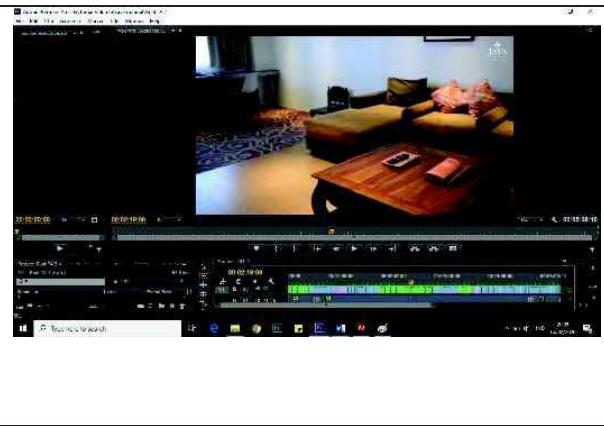 & $\begin{array}{l}\text { - } \text { Durasi : 2,36-2,43 menit } \\
\text { - } \text { Lokasi : kamar } \\
\text { Background } \\
\text { - Efek : Cross Dissolve } \\
\text { - Teknik : long shoot } \\
\text { - Pengambilan : atas } \\
\text { - Gambar : kamar } \\
\text { - Aktor : - }\end{array}$ \\
\hline 25 & 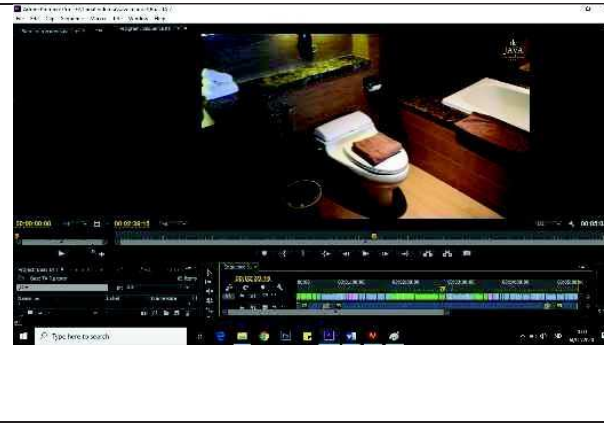 & $\begin{array}{l}\text { - Durasi : 2,43-2,48 menit } \\
\text { - Lokasi : kamar mandi } \\
\text { - Sound FX : Corporate } \\
\text { Background } \\
\text { - Efek : Cross Dissolve } \\
\text { - Teknik : long shoot } \\
\text { - Pengambilan : atas } \\
\text { - Gambar : kamar mandi } \\
\text { - Aktor : - }\end{array}$ \\
\hline
\end{tabular}




\begin{tabular}{|c|c|c|}
\hline No & Adegan & Durasi \\
\hline 26 & 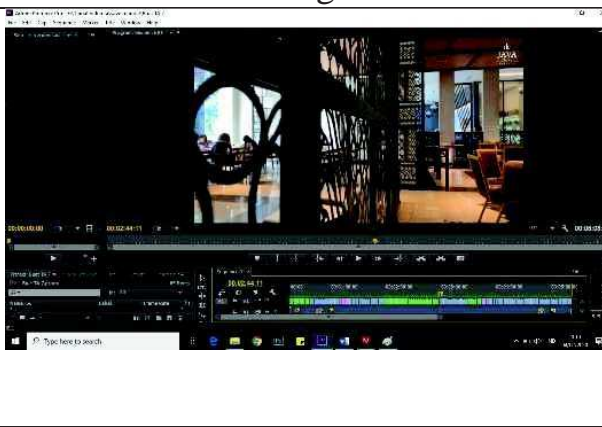 & $\begin{array}{l}\text { - } \text { Durasi : 2,48-2,51 menit } \\
\text { - Lokasi : de bale } \\
\text { - Sound FX : Corporate } \\
\text { Background } \\
\text { - Efek : Cross Dissolve } \\
\text { - Teknik : close up } \\
\text { - Pengambilan : maju } \\
\text { - Gambar : pintu } \\
\text { - Aktor : - }\end{array}$ \\
\hline 27 & 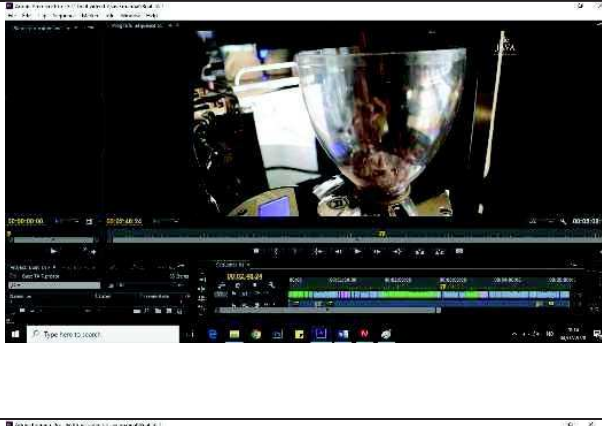 & $\begin{array}{l}\text { - Durasi : } 2,51-3,6 \text { menit } \\
\text { - Lokasi : cafe } \\
\text { - Sound FX : Corporate } \\
\text { Background } \\
\text { - Efek : Cross Dissolve } \\
\text { - Teknik : close up } \\
\text { - Pengambilan : samping } \\
\text { - Gambar : mesin coffee } \\
\text { - Aktor : - }\end{array}$ \\
\hline 28 & $\begin{array}{ll}- \\
\square \\
\square\end{array}$ & $\begin{array}{l}\text { - Durasi : } 3,6-3,14 \text { menit } \\
\text { - Lokasi : cafe } \\
\text { - Sound FX : Corporate } \\
\text { Background } \\
\text { - Efek : Cross Dissolve } \\
\text { - Teknik : close up } \\
\text { - Pengambilan : atas } \\
\text { - Gambar : coffee } \\
\text { - Aktor : - }\end{array}$ \\
\hline 29 & and & $\begin{array}{l}\text { - Durasi : } 3,14-3,24 \text { menit } \\
\text { - Lokasi : cafe } \\
\text { - Sound FX : Corporate } \\
\text { Background } \\
\text { - Efek : Cross Dissolve } \\
\text { - Teknik : close up } \\
\text { - Pengambilan : depan } \\
\text { - Gambar : cafe } \\
\text { - Aktor : Laki-laki }\end{array}$ \\
\hline 30 & $\frac{1}{100}$ & $\begin{array}{l}\text { - Durasi : 3,24-3,30 menit } \\
\text { - Lokasi : spa } \\
\text { - Sound FX : Corporate } \\
\text { Background } \\
\text { - Efek : Cross Dissolve } \\
\text { - Teknik : close up } \\
\text { - Pengambilan : samping } \\
\text { - Gambar : rempah } \\
\text { - Aktor : - }\end{array}$ \\
\hline
\end{tabular}




\begin{tabular}{|c|c|c|}
\hline No & Adegan & Durasi \\
\hline 31 & $\frac{1}{1}$ & $\begin{array}{l}\text { - Durasi : } 3,30-3,35 \text { menit } \\
\text { - Lokasi : gym } \\
\text { - Sound FX : Corporate } \\
\text { Background } \\
\text { - Efek : Cross Dissolve } \\
\text { - Teknik : long shoot } \\
\text { - Pengambilan : samping } \\
\text { - Gambar : alat gym } \\
\text { - Aktor : - }\end{array}$ \\
\hline 32 & 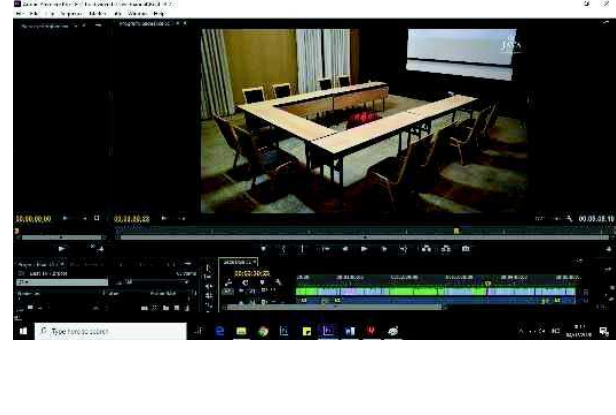 & $\begin{array}{l}\text { - Durasi : 3,35 - 3,39 menit } \\
\text { - Lokasi : meeting } \\
\text { - Sound FX : Corporate } \\
\text { Background } \\
\text { - Efek : Cross Dissolve } \\
\text { - Teknik : long shoot } \\
\text { - Pengambilan : - } \\
\text { - Gambar : meja } \\
\text { - Aktor : - }\end{array}$ \\
\hline 33 & 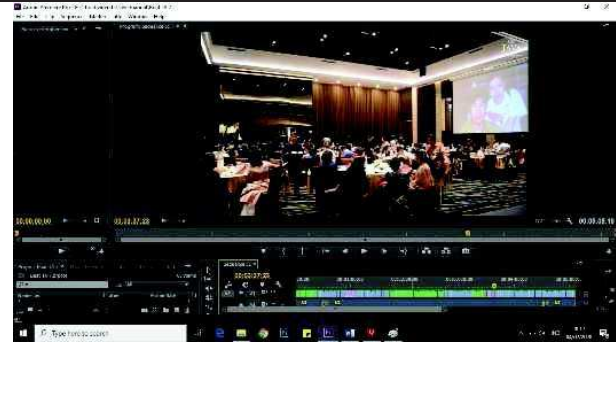 & $\begin{array}{l}\text { - Durasi : 3,39-3,42 menit } \\
\text { - Lokasi : meeting } \\
\text { - Sound FX : Corporate } \\
\text { Background } \\
\text { - Efek : Cross Dissolve } \\
\text { - Teknik : long shoot } \\
\text { - Pengambilan : maju } \\
\text { - Gambar : meja } \\
\text { - Aktor : - }\end{array}$ \\
\hline 34 & matem & $\begin{array}{l}\text { - Durasi : } \\
\text { 3,42-3,44 menit } \\
\text { - Lokasi : lift } \\
\text { - Sound FX : Corporate } \\
\text { Background } \\
\text { - Efek : Cross Dissolve } \\
\text { - Teknik : close up } \\
\text { - Pengambilan : depan } \\
\text { - Gambar : berjalan } \\
\text { - Aktor : Perempuan }\end{array}$ \\
\hline 35 & Hon & $\begin{array}{l}\text { - Durasi : } 3,44-3,47 \text { menit } \\
\text { - Lokasi : tangga } \\
\text { - Sound FX : Corporate } \\
\text { Background } \\
\text { - Efek : Cross Dissolve } \\
\text { - Teknik : close up } \\
\text { - Pengambilan : belakang } \\
\text { - Gambar : berjalan } \\
\text { - Aktor : Perempuan }\end{array}$ \\
\hline
\end{tabular}




\begin{tabular}{|c|c|c|}
\hline No & Adegan & Durasi \\
\hline 36 & $\begin{array}{ll}\frac{1}{2} \\
0\end{array}$ & $\begin{array}{l}\text { - Durasi : 3,47 - 3,53 menit } \\
\text { - Lokasi : tangga } \\
\text { - Sound FX : Corporate } \\
\text { Background } \\
\text { - Efek : Cross Dissolve } \\
\text { - Teknik : close up } \\
\text { - Pengambilan : depan } \\
\text { - } \text { memutar } \\
\text { - Gambar : berjalan } \\
\text { - Aktor : Perempuan }\end{array}$ \\
\hline 37 & $\frac{1}{2}$ & $\begin{array}{l}\text { - Durasi : } 3,53-4 \text { menit } \\
\text { - Lokasi : teras atas } \\
\text { - Sound FX : Corporate } \\
\text { Background } \\
\text { - Efek : Cross Dissolve } \\
\text { - Teknik : long shoot } \\
\text { - Pengambilan : samping } \\
\text { - Gambar : kursi } \\
\text { - Aktor : - }\end{array}$ \\
\hline 38 & 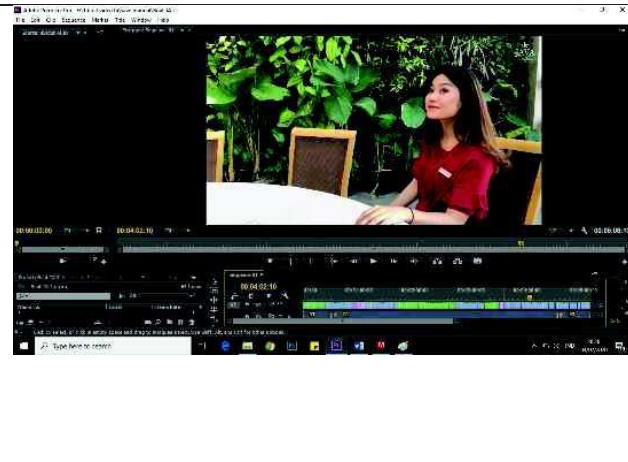 & $\begin{array}{l}\text { - Durasi : } 4-4,7 \text { menit } \\
\text { - Lokasi : teras atas } \\
\text { - Sound FX : Corporate } \\
\text { Background } \\
\text { - Efek : Cross Dissolve } \\
\text { - Teknik : close up } \\
\text { - Pengambilan : pinggir } \\
\text { - } \text { samping } \\
\text { - } \text { Aktombar : duduk } \\
\text { - Perempuan }\end{array}$ \\
\hline 39 & and & $\begin{array}{l}\text { - Durasi : 4,7 - 4,16 menit } \\
\text { - Lokasi : teras atas } \\
\text { - Sound FX : Corporate } \\
\text { Background } \\
\text { - Efek : Cross Dissolve } \\
\text { - Teknik : close up } \\
\text { - Pengambilan : belakang } \\
\text { - Gambar : kolam } \\
\text { - Aktor : Perempuan }\end{array}$ \\
\hline 40 & 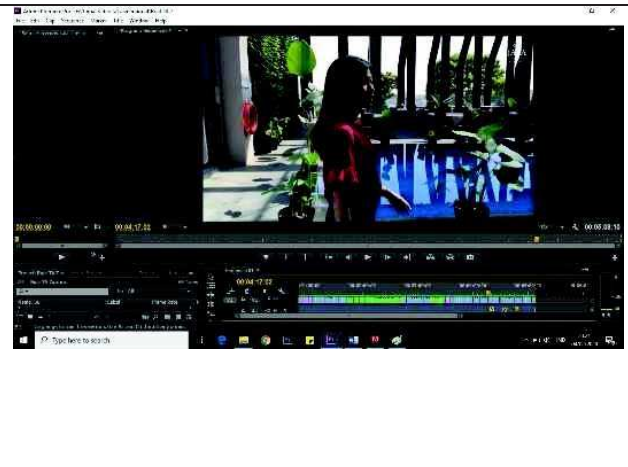 & $\begin{array}{l}\text { - Durasi : 4,16-4,23 menit } \\
\text { - Lokasi : kolam } \\
\text { - Sound FX : Corporate } \\
\text { Background } \\
\text { - Efek : Cross Dissolve } \\
\text { - Teknik : close up } \\
\text { - Pengambilan : samping } \\
\text { mengeliling } \\
\text { - Gambar : kolam } \\
\text { - Aktor : Perempuan }\end{array}$ \\
\hline
\end{tabular}




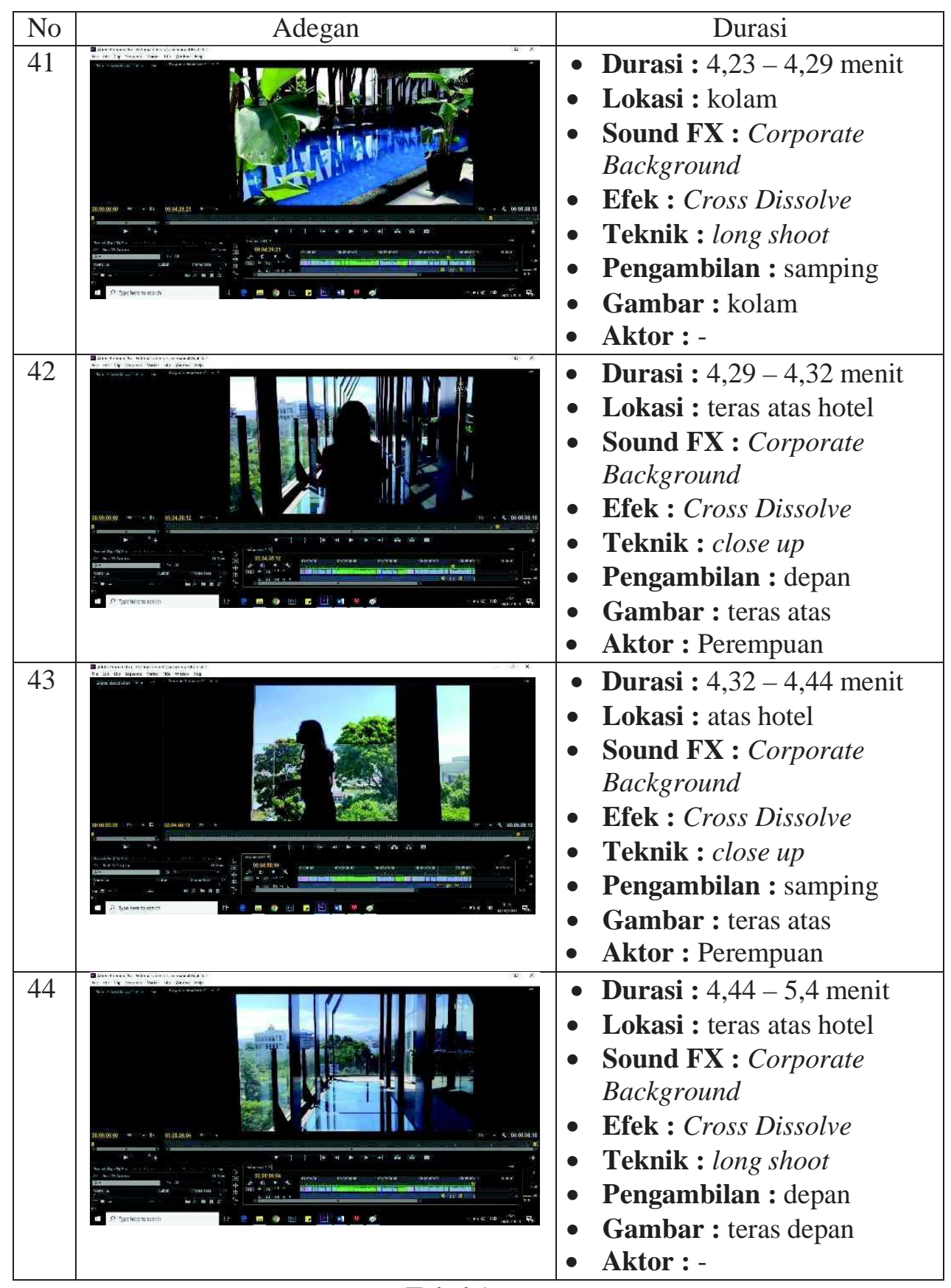

Tabel 1

Storyboard Akhir 


\section{Proses Rendering}

Pada bagian akhir ini dari keseluruhan proses produksi ataupun proses editing. Dalam Rendering, data-data yang sudah dimasukan dalam proses produksi dan editing akan di hasilkan dalam sebuah bentuk output video yang sudah di oleh dalam perangkat lunak adobe premiere pro cc.

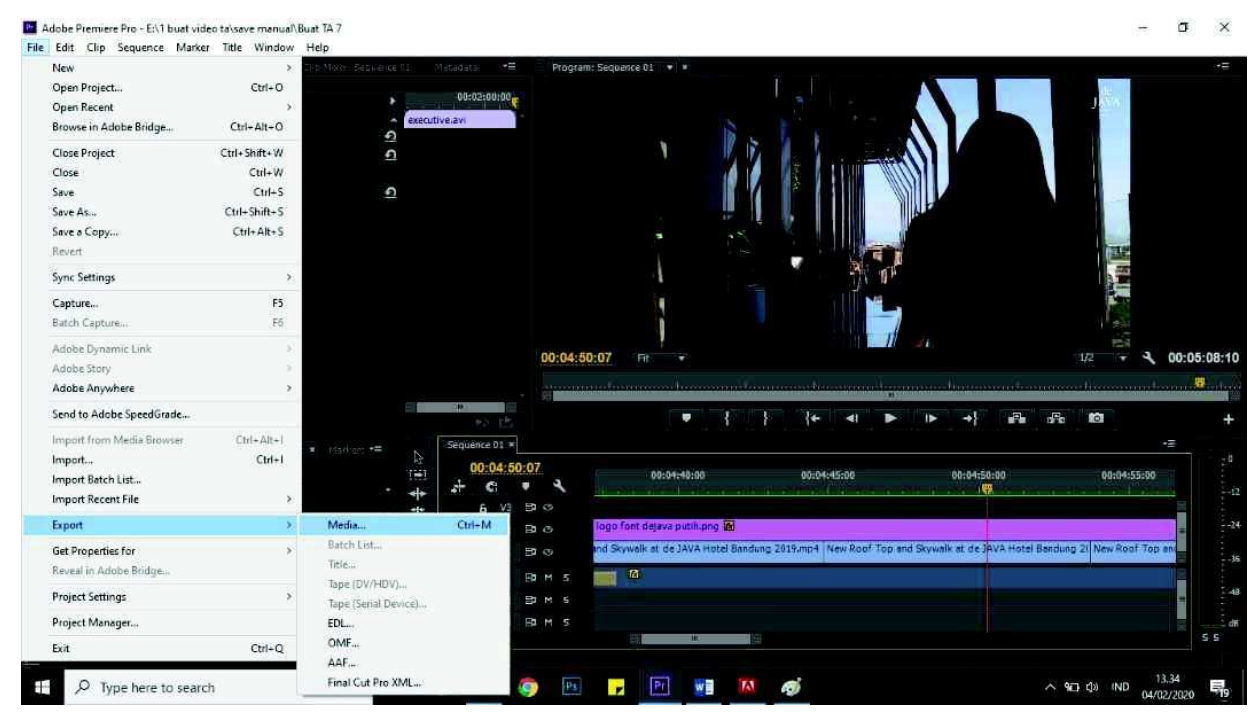

Gambar 5. Proses Rendering 1

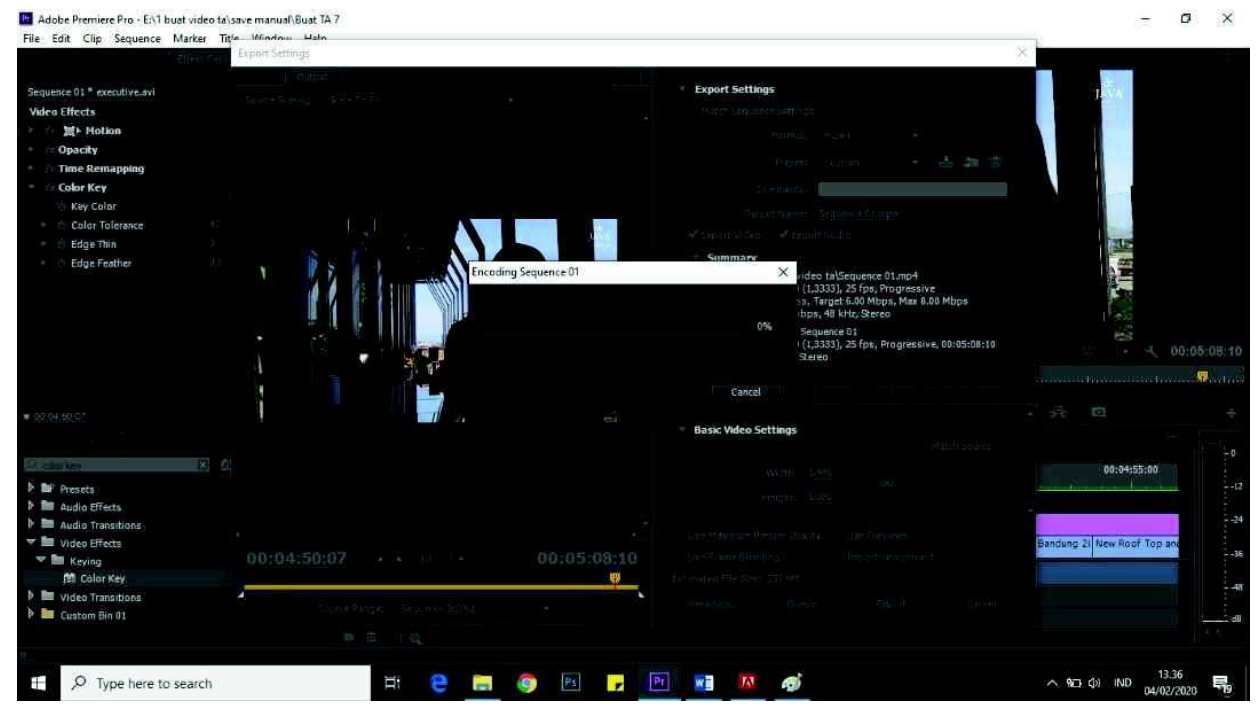

Gambar 6. Proses Rendering 2 


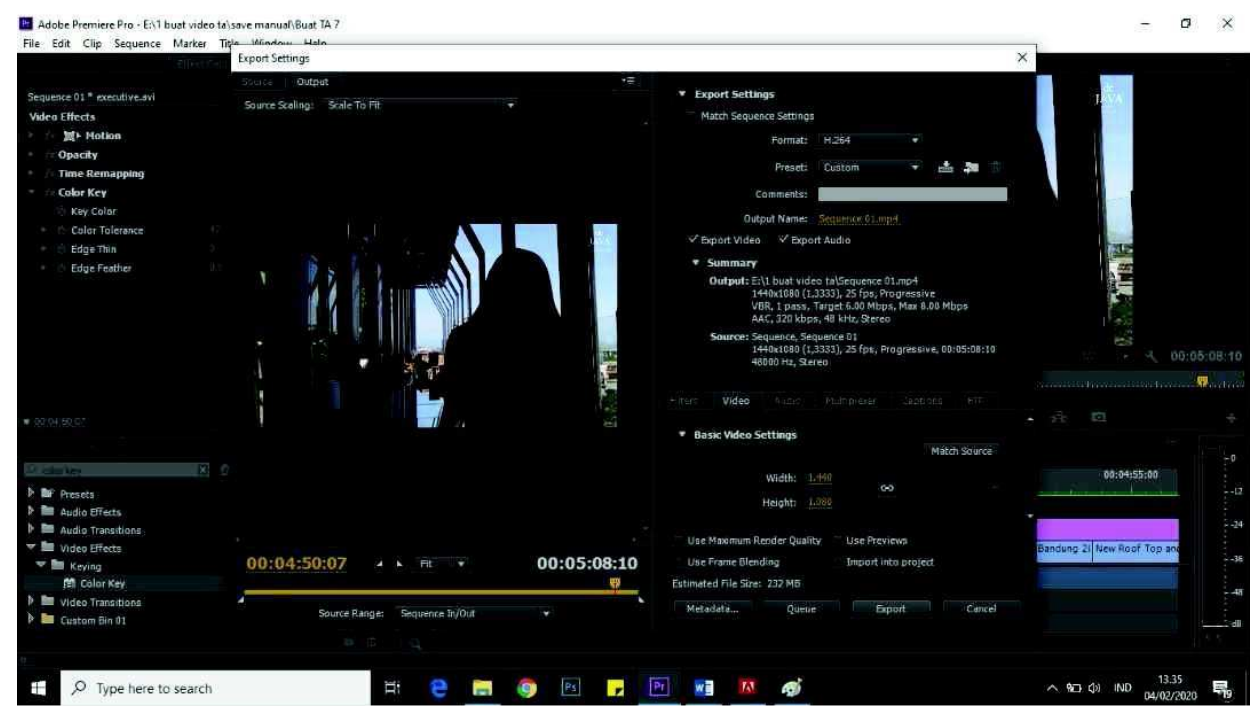

Gambar 7. Proses Rendering 3

\section{Kesimpulan}

Kesimpulan yang dapat penulis ambil dari penelitian ini adalah sebagai berikut :

a. Mengganti brosur dengan video company profile, sehingga pengunjung dapat melihat informasi secara audio visual.

b. Dengan adanya Company Profile ini, informasi yang diberikan oleh pihak hotel lebih mudah dipahami bagi masyarakat luas yang ingin mengetahui terlebih dahulu tentang hotel atau tempat menginap.

c. Adanya Company Profile ini juga memudahkan pihak hotel dalam mempromosikan atau menggunakan video ini di dalam media selain promosi.

\section{Daftar Pustaka}

[1] Aminudin. 2017. About Storyline. Bandung : Sinar Baru

[2] Andi.2009. Adobe Premiere Pro CS4. Yogyakarta : MADCOMS

[3] Anshori. 2015. Company Profile Sebagai Media Promosi. Jakarta : RajawaliPres

[4] Ayuningtyas. 2011. Ngedit Video Step by Step Menjadi Editing Profesional. Jakarta : Niaga Swadaya

[5] Binanto. 2010. Multimedia Digital Dasar Teori dan Pengembanganya. Yogyakarta : Andi

[6] Gregorius, Agung. 2019. Kupas Tuntas Adobe Premiere Pro CC. Yogtakarta MDCOMS MADIUN

[7] Hendratman, Hendi. 2017. The Magic Of Adobe Premiere Pro. Bandung : Informatika Bandung

[8] Halaz. 2012. Merancang Storyboard. Jakarta : Erlangga

[9] Kriyantono, R. 2008. Public Relations Writing: Teknik Produksi Media Public Relations dan Publisitas Korporat. 2nd ed. Jakarta : Kencana Prenada Media Group.

[10] Ladmadujin Bin Al-Bahra. Analisis dan Sistem Informasi. Jakarta : Balai Pustaka

[11] Luther. 2016. Memahami Storyboard. Jakarta : Gramedia Pustaka Utama

[12] My Earth. 2000. Perancangan Sistem dan Analisis. Malang : Bayu Media 
[13] Nurgiyantoro, Burhan. 2010. Teori Pengkajian Fiksi (Cetakan ke-10). Penerbit: Gadjah Mada University Press

[14] Paez, Sergio. 2016. Professional Storyboarding. Jakarta : Gramedia

[15] Primanda, Andya. 2017. Buku Pintar Penyunting Naskah. Jakarta : Gramedia Pustaka Utama

[16] Rahmawan, Arry. 1999. Cara Menyelesaikan Buku Naskah. Jakarta : Gagas Media

[17] Simarmata, Janner. 2012 Rekayasa Perangkat Lunak. Yogyakarta : Andi

[18] Tuloli, Nani. 2000. Kajian Sastra. Gorontalo. BMT "Nurul Jannah”.

[19] Thuan, Herman. 2014. Kreasi Company Profile Interaktif dengan Flash Action 3.0. Yogyakarta : Andi 